\title{
NOTE
}

\section{Wax and wane of eelgrass Zostera marina and water column silicon levels}

\author{
P. M. J. Herman*, M. A. Hemminga, P. H. Nienhuis ${ }^{*}$, J. M. Verschuure, E. G. J. Wessel ${ }^{* *}$ \\ Netherlands Institute of Ecology, Centre for Estuarine and Coastal Ecology, Vierstraat 28, 4401 EA Yerseke, The Netherlands
}

\begin{abstract}
Long-term observations in an enclosed estuarine branch in The Netherlands showed a remarkably strong correlation between water column levels of dissolved silicon (DSi) and standing stock of eelgrass Zostera marina. Si levels in the leaves of $Z$. marina varied between 0.02 and $0.66 \%$ of tissue dry weight; they were lower in the declining population than in other populations in neighbouring areas. We hypothesize that decreased concentrations of DSi, which may coincide with eutrophication of coastal waters, may be a factor in the worldwide decline of estuarine eelgrass populations whose significance has so far been ignored.
\end{abstract}

KEY WORDS: Seagrass - Eutrophication - Silicate $\cdot$ Coastal Estuaries - Nutrients

Seagrass populations all over the world are under stress as a result of changing environmental conditions in coastal waters. In many places this has resulted in a severe reduction of seagrass abundance, or even in the complete disappearance of these marine angiosperms (Peres \& Picard 1975, Orth \& Moore 1983, Shepherd et al. 1989, Larkum \& West 1990, Robblee et al. 1991, Philippart \& Dijkema 1995). Pinpointing the exact cause of seagrass decline in a given area often has been difficult (e.g. Kemp et al. 1983, Nienhuis 1983, Giesen et al. 1990), but it is widely acknowledged that eutrophication, caused by increased nutrient loading, is a factor of widespread importance (Duarte 1995). The mechanism usually proposed to explain the progressive decline of seagrasses in eutrophicated waters is an enhanced development of phytoplankton, epiphytic algae and macroalgae, which effectively compete with seagrasses for light (Duarte 1995, Short et al. 1995).

\footnotetext{
-E-mail: herman@cemo.nioo.knaw.nl

- Present address: Netherlands Institute of Ecology, Centre for Limnology, Rijksstraatweg 5, 3631 AC Nieuwersluis, The Netherlands
}

In this paper we put forward the hypothesis that an environmental factor which previously has not been considered in studies of seagrass vegetation, i.e. depletion of dissolved silicon (DSi) from the water column, may also be a cause of seagrass decline.

Methods and results. Our suggestion that DSi depletion is important in seagrass decline is based on longterm observations of eelgrass Zostera marina L. in an enclosed branch of the Rhine-Meuse Estuary, called The Grevelingen (SW Netherlands). In the framework of an extensive scheme of hydro-engineering works in the SW Netherlands following the severe flood disaster of 1953, The Grevelingen was cut off from the inflow of river water and from exchange with the North Sea by the construction of 2 dams, resulting in the formation of a $108 \mathrm{~km}^{2}$ saline lake in 1971. Due to persistent freshwater runoff, salinity slowly declined in the seventies, until in 1978 the connection between the lake and the North Sea was restored by means of a sluice. As a result of this adaptation, and through a policy of diverting agricultural runoff to other areas, The Grevelingen is now a meso- to oligotrophic lake with nearly marine salinity (Nienhuis 1992).

Since 1971 the areal cover of Zostera marina in The Grevelingen has been regularly monitored. Estimates of areal cover (to the nearest $10 \%$ ) were made by visual estimates from a boat sailing on transects approximately $1 \mathrm{~km}$ apart and stopping every $100 \mathrm{~m}$ over the whole area where water depth was less than $2.5 \mathrm{~m}$. In deeper waters, grid points spaced ca $1 \mathrm{~km}$ apart were inspected by SCUBA divers. These observations have been used to produce contour maps for cover classes. Cover maps for the seventies and early eighties are given by Nienhuis (1983). Areal cover showed conspicuous changes between 1971 and 1991. In 1978 a peak cover was reached, with all potential habitats being occupied (Nienhuis 1983). Currently, however, the population in the lake is on the brink of 
Table 1 Pearson correlation coefficients between mean Zostera marina cover and yearly median values of different environmental variables. Significance of the correlation coefficient was 'Bonferroni-corrected' for a total of 7 comparisons by multiplying the nominal significance level by $7 . \mathrm{n}$ is the number of yearly surveys of $Z$. marina for which a meaningful comparison could be made

\begin{tabular}{|lcccrcc|}
\hline & Ammonium & Nitrate + nitrite & Phosphate & Salinity & Silicon & Secchi disk depth \\
\hline Pearson correlation coefficient & 0.504 & 0.241 & 0.608 & -0.654 & 0.914 & -0.186 \\
Bonferroni-corrected probability & 0.98 & 1 & 0.329 & 0.280 & 0.001 & 1 \\
$\mathrm{n}$ & 11 & 10 & 11 & 10 & 11 & 11 \\
\hline
\end{tabular}

extinction. From the distribution maps of $Z$. marina we calculated the spatially averaged cover of the whole system. For this purpose, the surface area occupied by each of the different coverage classes on the maps was multiplied by the mean percentage cover of the class, the results were summed, and the sum was divided by the total wet surface area of The Grevelingen. Detailed water quality monitoring data from 8 sampling stations that spatially cover The Grevelingen were provided by Rijkswaterstaat (RIKZ) ${ }^{1}$. Yearly running means, as well as yearly median values, of silicate, ammonium, nitrate + nitrite, phosphate, salinity and light attenuation were calculated based on available monitoring data at different stations. For a given variable, data from all stations were pooled. In the following, the median value of all observations of a variable within each year is presented as the representative value for that year. However, no qualitative differences with an analysis based on yearly running means could be found.

Pearson correlation coefficients (and Bonferronicorrected probabilities) between Zostera marina cover and the water quality variables, expressed as yearly median values, are given in Table 1. Dissolved silicon was the only variable yielding a significant correlation (Fig. 1). A comparable relation with other environmental parameters (Fig. 2) could not be found. The same conclusion was drawn from the correlation with yearly mean values of the environmental variables.

Nevertheless, the relation between salinity and eelgrass cover was analysed in more detail. Freshwater is the main source of DSi in the marine environment (Tréguer et al. 1995), and one could propose that salinity is the master factor affecting eelgrass. Although Zostera marina thrives well in fully marine seawater, and no adverse effects of salinity have been described for salinities up to $33 \%$ (Giesen et al. 1990), germination and, consequently, establishment of eelgrass plants

\footnotetext{
${ }^{1}$ Until 1987 these data were published quarterly as 'Kwaliteitsonderzoek in de rijkswateren' by Rijkswaterstaat, Den Haag. These reports contain details on the methods used. Data for the period since 1987 are avallable in electronic format from Rijkswaterstaat
}

could be negatively affected by high salinities (Hootsmans et al. 1987). We tested this possibility by dividing The Grevelingen into different sub-areas according to the frequency of occurrence of $Z$. marina in the 11 annual surveys: optimal habitats ( $Z$. marina occurring in 9 or more surveys), suboptimal habitats (occurring between 4 and 8 times) and marginal habitats (occurring between 1 and 3 times). At least in the optimal habitats, $Z$. marina is known to occur as a truly perennial population, where germination from seeds is restricted to open spots in the vegetation. The average cover in the 3 sub-areas had an almost exactly parallel time evolution (correlation coefficients between the log-transformed series were $0.97,0.91$ and 0.85 for optimal-suboptimal, optimal-marginal and suboptimalmarginal respectively; $n=11$ ). This suggests that a common factor affecting growth rather than germination and (re)establishment of $\mathcal{Z}$. marina is responsible for the time dynamics of eelgrass in The Grevelingen.

No data have been published so far on the occurrence of Si in seagrasses, nor on the possible functional significance of Si for these plants. We measured Si levels in Zostera marina leaves from plants collected in The Grevelingen, and from nearby populations in

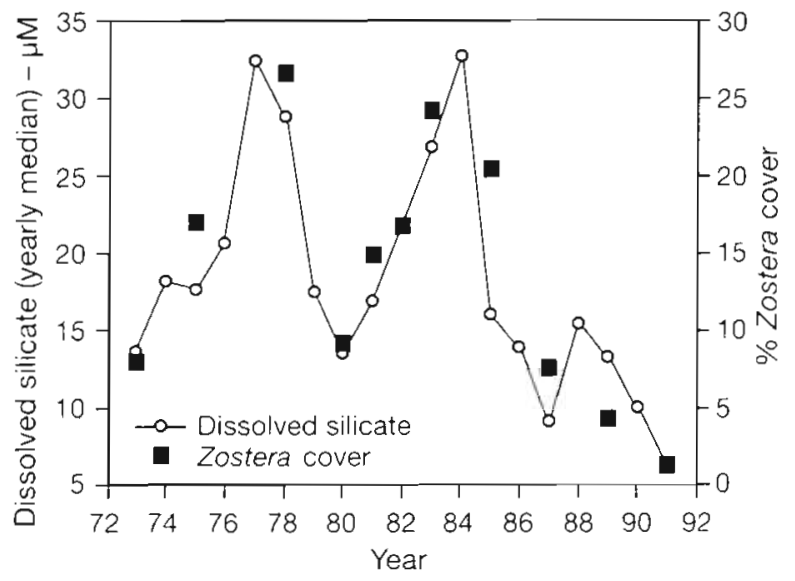

Fig. 1. Time course of average \% cover of Zostera marina over The Grevelingen (The Netherlands), and yearly median values of dissolved silicate concentrations 

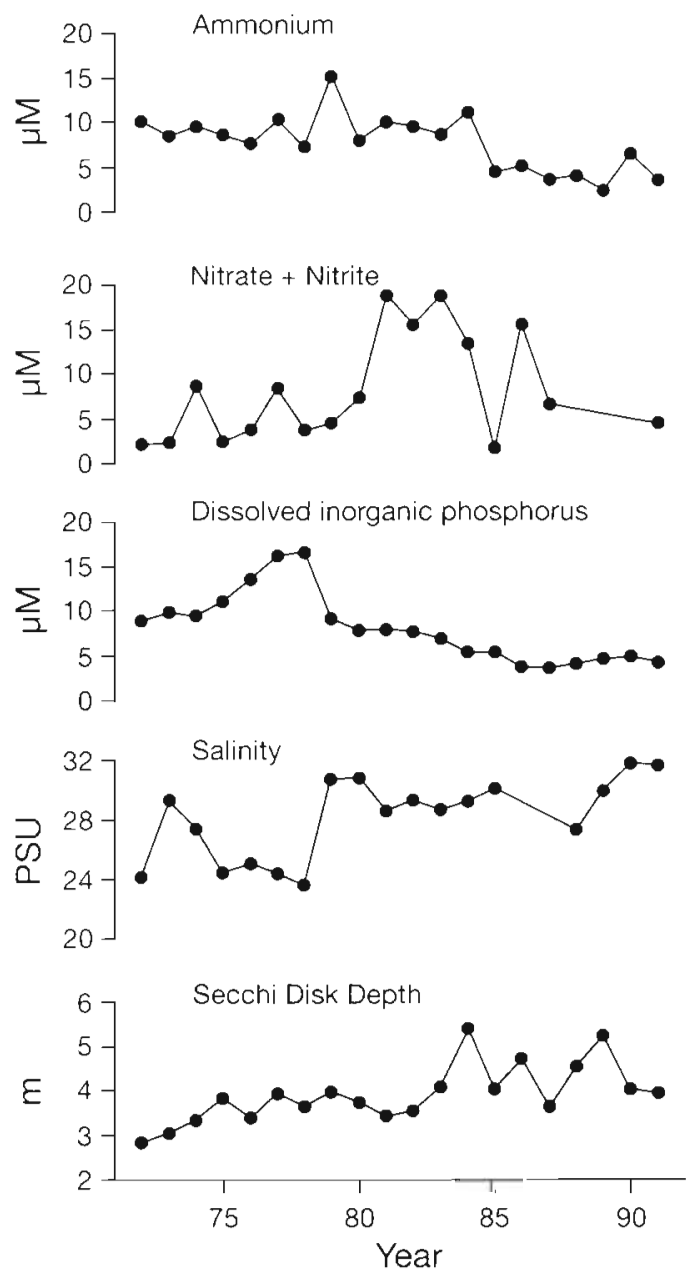

Fig. 2. Time course of dissolved ammonium, dissolved nitrate + nitrite, dissolved inorganic phosphorus, salinity and Secchi disk depth in The Grevelingen (The Netherlands) from 1972 to 1991 Data on salinity and nitrate + nitrite were not available during part of the monitoring programme. Data courtesy of Rijkswaterstaat (RIKZ)

brackish Lake Veere and in an embayment of the Oosterschelde (an arm of the North Sea) called Zandkreek. The latter 2 populations do not show the dramatic decline observed in The Grevelingen population in the last decade. Leaf material was collected between 6 July and 7 August 1994. At each of the locations 3 or 4 samples of $Z$. marina plants were collected and stored at $7^{\circ} \mathrm{C}$ until further processing. During this period $(<24 \mathrm{~h})$ the plants were kept in water from their respective collection sites. In the laboratory, leaves from each sample were pooled according to sequence of formation along the shoots. The mature 2 nd to 5 th leaves were cleaned with filter paper to remove epiphytes and briefly rinsed in demineralized water prior to analyses of $\mathrm{Si}, \mathrm{C}$ and $\mathrm{N}$ content. The first (youngest) leaves were not included in the analyses because of their immaturity and small size, which made reliable chemical analyses difficult; older ( $>5$ th) leaves were discarded because these leaves were mostly in an advanced state of senescence or were dead. Determination of Si content of the leaf samples was carried out after microwave dissolution of the material with $\mathrm{INO}_{3}$. $\mathrm{HCl}$ and $\mathrm{HF}$; detection by atomic absorption spectrophotometry (Perkin Elmer AAS 2380) in an acetylene/ dinitrogenoxide flame followed Novozamski et al. (1984)

No trends in the relation between Si content and leaf age were present (ANOVA $>0.05$ ). The leaf Si content in the samples varied between 0.02 and $0.66 \%$ of the dry weight (DW). In comparison, the median level of the macronutrient nitrogen in seagrasses lies just below $2 \%$ (Duarte 1990). The Si content of The Grevelingen samples were all on the low end of the scale, varying between 0.02 and $0.11 \%$ DW (mean $\pm \mathrm{SD}$ : $0.06 \pm 0.027 \%, \mathrm{n}=12)$. Si levels of the samples collected from the other locations were significantly higher (Lake Veere: $0.46 \pm 0.14 \%, \mathrm{n}=12$; Zandkreek: $0.296 \pm 0.077 \%, \mathrm{n}=15$ ). This comparison shows that Si levels in different populations are not invariable. More replication of habitats would be needed to correlate the leaf concentration with the health of the populations.

Discussion. Based on the correlation found in this study we hypothesize that the wax and wane of the Zostera marina population in The Grevelingen in recent decades could be functionally related to the fluctuating DSi levels. The currently restricted availability of silicon to the plants is reflected in the low levels of silicon in the leaves as compared to the levels in other populations.

The functional role of Si in Zostera marina as yet can only be a matter of speculation. Silicon is an element found in the tissues of many plant families, accumulating largely as a polymer of hydrated amorphous silica $\left(\mathrm{SiO}_{2} \cdot \mathrm{nH}_{2} \mathrm{O}\right)$ (Kaufman et al. 1981, Sangster \& Hodson 1986). Concentrations of Si in terrestrial plants vary between 0.1 and $10 \%$ on a dry weight basis (Epstein 1994), but we know of no data on seagrasses. There is good evidence that Si promotes growth of monocotyledonous plants; in several species this effect is clearly related to increased rigidity of stems and leaves, which favors light interception (Epstein 1994). In addition, there is growing evidence that increased Si absorption may offer protection against fungal diseases, possibly by a more rapid and extensive activation of plant defense mechanisms (Bélanger et al. 1995). Whatever the exact role of silicon in eelgrass, the observed correlation in the time series, the concentrations of Si found and the known physiological role of $\mathrm{Si}$ in other plant species together form a basis for the hypothesis that the availability of DSi may be essential for the persistence of eelgrass populations and, hence, 
that depletion of water DSi reservoirs may herald their decline. It is clear, however, that the presently available evidence does not provide proof for this hypothesis. Alternative explanations could be that both dissolved Si and eelgrass cover would be related to a third, causal factor, or that different limitations (e.g. light limitation in early years, $\mathrm{N}$ and/or $\mathrm{P}$ limitation in later years) would in combination have caused the fluctuation of eelgrass cover. As discussed earlier, we think it is improbable that salinity (the obvious choice for a third factor) is causally involved with $Z$. marina dynamics. Compared to the 'combined factor' hypothesis, the Si hypothesis at least offers the advantage of parsimony. Neither direct toxicity of nitrate, as proposed by Burkholder et al. (1992), nor the negative impact of nitrogen loading on eelgrass production, as reported by Short et al. (1995), seems to play a major role in the present data set. Under these hypotheses, one would expect a negative correlation between $Z$. marina cover and nitrogen variables in the water, which is not the case.

DSi [mostly silicic acid, $\mathrm{Si}(\mathrm{OH})_{4}$ ] is supplied to the marine environment mainly by riverine inputs (Tréguer et al. 1995). The DSi load of rivers is the result of physico-chemical weathering of the continental crust and is normally not a consequence of human activities. This contrasts with the increased fluxes of nitrogen and phosphorus from land to sea in historical times, which are strongly coupled to the activities of growing human populations (Forsberg 1995). Notwithstanding the fact that DSi land runoff is nearly exclusively the result of natural physico-chemical processes, receiving aquatic systems such as lakes and coastal seas have frequently shown decreasing DSi water column concentrations in recent times, coincident with anthropogenically increased nitrogen and phosphorus inputs (Officer \& Ryther 1980, Conley et al. 1993). This phenomenon has been ascribed to nutrient-enhanced production of diatoms (Schelske \& Stoermer 1971, 1972, Officer \& Ryther 1980), in combination with increased deposition and preservation of the siliceous diatom valves in the sediments (Conley et al. 1993), ultimately leading to depletion of water column reservoirs of DSi. In the phytoplankton, shifts in the species composition from diatoms to flagellates and cyanobacteria have been described as the results of changes in nutrient ratios (Smayda 1990).

The currently decreasing concentration of DSi in The Grevelingen is not a phenomenon accompanying eutrophication of the lake, but is probably the result of the absence of substantial land runoff in combination with the long residence time of the water (several months; Nienhuis 1983). Consequently, the replenishment of the DSi reservoir of the lake will be virtually dependent on the regeneration of Si through decom- position of diatoms, which is a slow process compared to fixation of DSi in production (Officer \& Ryther 1980). However, the worldwide decrease in loads of DSi carried by eutrophicated rivers (Justic et al. 1995, Tréguer et al. 1995) may imply that DSi depletion is a present reality or a looming perspective for many coastal systems, particularly semi-enclosed ones with long hydrodynamic residence times. Research on the significance of DSi for seagrasses in coastal systems therefore is surely needed.

Acknowledgements. We thank Prof. Dr C. Heip, Prof. Dr W van Vierssen and Dr J. Middelburg for discussion of the concepts proposed here. This is NIOO-CEMO publication no. 2190

\section{LITERATURE CITED}

Bélanger RR, Bowen PA, Ehret DL, Menzies JG (1995) Soluble silicon. Its role in crop and disease management of greenhouse crops. Plant Dis 79:329-336

Burkholder JM, Mason M, Glasgow HB Jr (1992) Watercolumn nitrate enrichment promotes decline of eelgrass Zostera marina: evidence from seasonal mesocosm experiments. Mar Ecol Prog Ser 81:163-178

Conley DJ, Schelske CL, Stoermer EF (1993) Modification of the biogeochemical cycle of silica with eutrophication. Mar Ecol Prog Ser 101:179-192

Duarte CM (1990) Seagrass nutrient content. Mar Ecol Prog Ser 67:201-207

Duarte CM (1995) Submerged aquatic vegetation in relation to different nutrient regimes. Ophelia 41:87-112

Epstein E (1994) The anomaly of silicon in plant biology. Proc Natl Acad Sci USA 91:11-17

Forsberg $C$ (1995) The large-scale flux of nutrients from land to water and the eutrophication of lakes and marine waters. Mar Pollut Bull 29:409-413

Giesen WBJT, Van Katwijk MM, Den Hartog C (1990) Temperature, salinity, insolation and wasting disease of eelgrass (Zostera marina L.) in the Dutch Wadden Sea in the 1930's. Neth. J Sea Res 25:395-404

Hootsman MJM, Vermaat JE, Van Vierssen W (1987) Seedbank development, germination and early seedling survival of two seegrass species from The Netherlands: Zostera marina L. and Zostera noltii Hornem. Aquat Bot 28:275-285

Justic D, Rabalais NN. Turner RE (1995) Stoichiometric nutrient balance and origin of coastal eutrophication. Mar Pollut Bull 30:41-46

Kaufman PB, Dayanandan P, Takeoka Y, Bigelow WC, Jones JD, Iler R (1981) Silica in shoots of higher plants. In: Simpson TL, Volcani BE (eds) Silicon and siliceous structures in biological systems. Springer Verlag, Berlin, p 409-449

Kemp WM, Boynton WR, Twilley RR, Stevenson JC, Means JC (1983) The decline of submerged vascular plants in upper Chesapeake Bay: summary of results concerning possible causes. Mar Soc Technol J 17:78-89

Larkum AWD, West RJ (1990) Long-term changes of seagrass meadows in Botany Bay, Australia. Aquat Bot 37:55-70

Nienhuis PH (1983) Temporal and spatial patterns of eelgrass (Zostera marina L.) in a former estuary in The Netherlands, dominated by human activities. Mar Technol Soc J $17: 69-77$ 
Nienhuis PH (1992) Ecology of coastal lagoons in the Netherlands (Veerse Meer and Grevelingen). Vie Milieu 42:59-72

Novozamski I, van Eck R, Houba VJG (1984) A rapid determination of silicon in plant material. Comm Soil Sci Plant Anal 15:205-224

Officer CB, Ryther JH (1980) The possible importance of silicon in marine eutrophication. Mar Ecol Prog Ser 3:83-91

Orth RJ, Moore KA (1983) Chesapeake Bay: an unprecedented decline in submerged aquatic vegetation. Science 22:51-52

Peres JM, Picard J (1975) Causes de la raréfaction et de la disparition des herbiers de Posidonia oceanica sur les côtes françaises de la Méditerranée. Aquat Bot 1:133-139

Philippart CJM, Dijkema KS (1995) Wax and wane of Zostera noltii in the Dutch Wadden Sea. Aquat Bot 49:255-268

Robblee MB, Barber TR, Carlson PR Jr, Durako MJ, Fourqurean JW, Muehlstein LK, Porter D, Yarbro LA Zieman RT, Zieman JC (1991) Mass mortality of the tropical seagrass Thalassia testudinum in Florida Bay (USA). Mar Ecol Prog Ser 71:297-299

Sangster AG, Hodson MJ (1986) Silica in higher plants. In: Silicon biochemistry (CIBA Found. Symp. 121). Wiley,

This note was submitted to the editor
New York, p 90-111

Schelske CL, Stoermer EF (1971) Eutrophication, silica depletion, and predicted changes in algal quality in Lake Michigan. Science 173:423-424

Schelske CL, Stoermer EF (1972) Phosphorus, silica and eutrophication in Lake Michigan. In: Likens GE (ed) Nutrients and eutrophication. American Society of Lumnology and Oceanography, Lawrence, KS, p 157-171

Shepherd SA, McComb AJ, Bulthuis DA, Neverauskas V. Steffensen DA (1989) Decline of seagrasses. In: Larkum ADW, McComb AJ, Shepherd SA (eds) Biology of seagrasses. Elsevier, Amsterdam, p 346-393

Short FT, Burdick DM, Kaldy JE III (1995) Mesocosm experiments quantify the effects of eutrophication on eelgrass, Zostera marina. Limnol Oceanogr 40:740-749

Smayda TJ (1990) Novel and nuisance phytoplankton blooms in the sea: evidence for global epidemic. In: Graneli $E_{\text {, }}$ Sundstrom B, Edler E, Anderson DM (eds) Toxic marine phytoplankton. Elsevier, Amsterdam, p 29-40

Tréguer P, Nelson DM, Van Beusekom AJ, DeMaster DJ, Leynaert A, Quéguiner B (1995) The silica balance in the world ocean: a reestimate. Science 268:375-379

Manuscript first received: January 12, 1996

Revised version accepted: October 29, 1996 